\begin{tabular}{|c|c|c|c|}
\hline \multirow{3}{*}{$\begin{array}{r}\text { Case Reports in } \\
\text { Gastroenterology }\end{array}$} & \multirow{2}{*}{\multicolumn{2}{|c|}{ Case Rep Gastroenterol 2016;10:264-268 }} & \multirow[b]{3}{*}{$\begin{array}{l}\text { Karger } \\
\text { Open access }\end{array}$} \\
\hline & & & \\
\hline & $\begin{array}{l}\text { DOI: 10.1159/000446838 } \\
\text { Publisned onilne: June 6, } 2016\end{array}$ & $\begin{array}{l}\text { (c) } 2016 \text { The Author(s) } \\
\text { Published by S. Karger AG, Basel } \\
\text { www.karger.com/crg }\end{array}$ & \\
\hline & $\begin{array}{l}\text { This article is licensed under } \\
\text { International License (CC BY-I } \\
\text { Usage and distribution for comr }\end{array}$ & $\begin{array}{l}\text { mons Attribution-NonCommercial } 4.0 \\
\text { rger.com/Services/OpenAccessLicense). } \\
\text { quires written permission. }\end{array}$ & \\
\hline
\end{tabular}

\title{
Superior Mesenteric Vein Thrombosis Associated with Hormonal Contraceptive Use
}

\author{
Nobuatsu Koyama \\ Department of Surgery, Tsuboi Hospital, Fukushima, Japan
}

\section{Keywords}

Superior mesenteric vein thrombosis $\cdot$ Hormonal contraceptive $\cdot$ Anticoagulant infusion

\begin{abstract}
A 44-year-old woman was admitted with a 7-day history of lower abdominal pain and nausea. Physical examination demonstrated tenderness in the lower abdomen without signs of peritonitis. There were no specific findings in the laboratory evaluation. She had a history of dysmenorrhea for 15 years and was taking a combined hormonal contraceptive containing $0.02 \mathrm{mg}$ ethinyl estradiol and $3 \mathrm{mg}$ drospirenone for 19 months. Contrast-enhanced computed tomography showed superior mesenteric vein thrombosis (SMVT). Systemic anticoagulant infusion was immediately administered and the symptoms disappeared within 2 days. The thrombus disappeared after 3 months. This case report suggests that early diagnosis of SMVT and immediate systemic anticoagulant therapy may reduce the rate of intestinal infarction.

(C) 2016 The Author(s)

Published by S. Karger AG, Basel
\end{abstract}

\section{Introduction}

Most venous thrombotic events secondary to contraceptives present as deep vein leg thrombosis and pulmonary embolism [1]. The superior mesenteric vein (SMV) is a rare site of thrombosis [2]. The first report of SMV thrombosis (SMVT) associated with contraceptives was by Reed et al. [3] in 1963. Diagnosis is sometimes difficult because of nonspecific ab- 
dominal symptoms and physical findings [4], and delayed diagnosis causes extensive intestinal ischemia with a high risk of mortality. Contrast-enhanced computed tomography (CT) facilitates early diagnosis of SMVT, with a sensitivity of more than $90 \%$ [5].

We report a case of SMVT associated with hormonal contraceptive use; the correct diagnosis was made with contrast-enhanced CT, and the patient was immediately treated with systemic anticoagulants, thereby avoiding bowel resection.

\section{Case Report}

A 44-year-old woman presented with lower abdominal pain for 7 days. She described a dull pain and abdominal fullness that persisted for the first 2 days; however, there was no vomiting or fever. On the fourth day, she was examined by her primary care physician and was prescribed an $\mathrm{H} 2$ blocker, but her symptoms were not relieved. She was referred to our hospital 7 days after onset of symptoms. A physical examination on admission demonstrated tenderness in the lower left quadrant with slight abdominal distention. There were no signs of peritonitis. She was well nourished, had a body mass index of 26.4, and was afebrile with normal vital signs. The laboratory examination results were within the normal ranges except for C-reactive protein $6.17 \mathrm{mg} / \mathrm{dl}$ (normal range, <0.45). She had a history of dysmenorrhea for 15 years and had been taking a combined hormonal contraceptive containing $0.02 \mathrm{mg}$ ethinyl estradiol and $3 \mathrm{mg}$ drospirenone for 19 months. She denied smoking, history of thrombosis, or recent surgery.

Contrast-enhanced CT revealed an intraluminal filling defect in the SMV extended to the peripheral vein of the jejunum, and mesenteric edema was present (fig. 1). The bowel wall enhancement was preserved and peritoneal fluid was absent.

The patient was systemically treated with $18,000 \mathrm{IU} /$ day heparin, 240,000 IU/day urokinase, and $2 \mathrm{~g} /$ day cefmetazole sodium. Her symptoms gradually subsided 2 days after the initiation of therapy, which was replaced with warfarin on the sixth day. A contrastenhanced CT on the 13th day showed recanalization of the SMV with a small amount of thrombus (fig. 2). The thrombus disappeared after 3 months (fig. 3). Follow-up examination demonstrated normal antithrombin III, protein C, and protein $\mathrm{S}$ activity.

\section{Discussion}

SMVT is uncommon, with a reported incidence of $5-15 \%$ of all cases of mesenteric vessel occlusive disease [6]; it is considered an abdominal emergency with a high rate of intestinal infarction, if not diagnosed immediately and treated properly.

The increased risk of venous thrombosis among contraceptive users is well known. Lidegaard et al. [1] reported that the overall absolute risk of venous thrombosis in nonusers of oral contraceptives was 3.01 per 10,000 woman years, and was 6.29 in current users. The adverse effects of estrogen-progestin combined oral contraceptives, such as thrombosis, are thought to be related to the estrogen component [2], and the risk of thrombosis decreases with lowering of the estrogen dose and shortening the duration of use [1,2]. Our patient had been taking combined oral contraceptives $(0.02 \mathrm{mg}$ ethinyl estradiol and $3 \mathrm{mg}$ drospirenone) for 19 months. The risk of venous thrombosis reportedly changes with the type of progestogen, and users of combined contraceptives with drospirenone have twice the risk of thrombosis compared to users of contraceptives with levonorgestrel [7]. Hormonal contra- 
ceptives affect a large number of hemostatic variables $[8,9]$ and may induce intimal hyperplasia [9]. However, it is difficult to predict which women will develop a thrombosis. Of 2,045 cases of venous thrombotic events among users of contraceptives, deep vein leg thrombosis occurred in $61.8 \%$ of cases, pulmonary embolism in $26.2 \%$, and portal thrombosis in $1.2 \%$ [1]. Yang et al. [10] reported that cases associated with contraceptive use accounted for 3 of 43 SMVT patients. In spite of its low incidence, we should have an accurate understanding of SMVT associated with contraceptive use because of the high incidence of intestinal infarction.

Diagnosis in the early stages of SMVT is difficult because patients usually present with nonspecific abdominal symptoms, and commonly describe as dull pain with bloating. The hallmark is pain that is disproportional to the physical findings [4]. It is important to take a detailed personal history including prescriptions, and keep in mind SMVT as one of the possible adverse effects of hormonal contraceptives.

Contrast-enhanced CT facilitates early diagnosis, with a sensitivity of more than $90 \%$ [5]. It is not only the most useful early diagnostic modality, but also a useful tool for making decisions about nonoperative management, which includes confirming viability of the intestine by observing the enhancement of the bowel wall [10].

Brunaud et al. [11] reported that 11 of 12 acute mesenteric venous thrombosis patients were treated with anticoagulation alone; morbidity occurred in $16.6 \%$ and mortality in $25 \%$. They also reported that nonoperative management with systemic anticoagulation for acute mesenteric venous thrombosis is feasible when the initial diagnosis with a CT scan is certain, because no statistical difference in morbidity and mortality was observed between the initial operation group and the nonoperative group [11].

Meanwhile, Yang et al. [10] reported that $79 \%$ of 43 patients initially received treatment with systemic anticoagulants, and 4 improved without any other treatment. They reported that 19 patients underwent catheter-directed thrombolysis and that 20 required emergency surgery. They emphasized that early catheter-directed thrombolysis is one of the most effective measures to avert intestinal infarction [10].

In our case, systemic anticoagulant therapy and discontinuation of contraceptives led to complete recovery; however, if the condition is not relieved, we must not hesitate to perform additional therapy, such as catheter-directed thrombolysis or laparotomy.

\section{Statement of Ethics}

Written informed consent for this report was obtained from the patient. Patient records were anonymously and retrospectively analyzed.

\section{Disclosure Statement}

The author declares that there is no conflict of interests regarding the publication of this paper.

\section{References}

Lidegaard Ø, Løkkegaard E, Svendsen A, et al: Hormonal contraception and risk of venous thromboembolism: national follow-up study. BMJ DOI: 10.1136/bmj.b2890. 


\section{Case Reports in Gastroenterology}

\begin{tabular}{l|l}
\hline Case Rep Gastroenterol 2016;10:264-268 \\
\hline $10.1159 / 000446838$ & $\begin{array}{l}\text { @ 2016 The Author(s). Published by S. Karger AG, Basel } \\
\text { www.karger.com/crg }\end{array}$ \\
\hline
\end{tabular}

Koyama: Superior Mesenteric Vein Thrombosis Associated with Hormonal Contraceptive Use

-2 Hassan HA: Oral contraceptive-induced mesenteric venous thrombosis with resultant intestinal ischemia. J Clin Gastroenterol 1999;29:90-95.

-3 Reed DL, Coon WW: Thromboembolism in patients receiving progestional drugs. N Engl J Med 1963;269:622-624.

4 Choudhary AM, Grayer D, Nelson A, et al: Mesenteric venous thrombosis: a diagnosis not to be missed! J Clin Gastroenterol 2000;31:179-182.

-5 Morasch MD, Ebaugh JL, Chiou AC, et al: Mesenteric venous thrombosis: a changing clinical entity. J Vasc Surg 2001;34:680-684.

-6 Grendell JH, Ockner RK: Mesenteric venous thrombosis. Gastroenterology 1982;82:358-372.

-7 Lidegaard $\emptyset$, Nielsen LH, Skolund CW, et al: Risk of venous thromboembolism from use of oral contraceptives containing different progestogens and oestrogen doses: Danish cohort study, 20012009. BMJ DOI: $10.1136 /$ bmj.d6423.

8 Kluft C, Lansink M: Effect of oral contraceptives on haemostasis variables. Thromb Haemost 1997;78:315-326.

9 Miller DR: Unusual focal mesenteric venous thrombosis associated with contraceptive medication: a case report. Ann Surg 1971;173:135-138.

10 Yang S, Fan X, Ding W, et al: Multidisciplinary stepwise management strategy for acute superior mesenteric venous thrombosis: an intestinal stroke center experience. Thromb Res 2015;135:36-45.

11 Brunaud L, Antunes L, Collinet-Adler S, et al: Acute mesenteric venous thrombosis: case for nonoperative management. J Vasc Surg 2001;34:673-679.

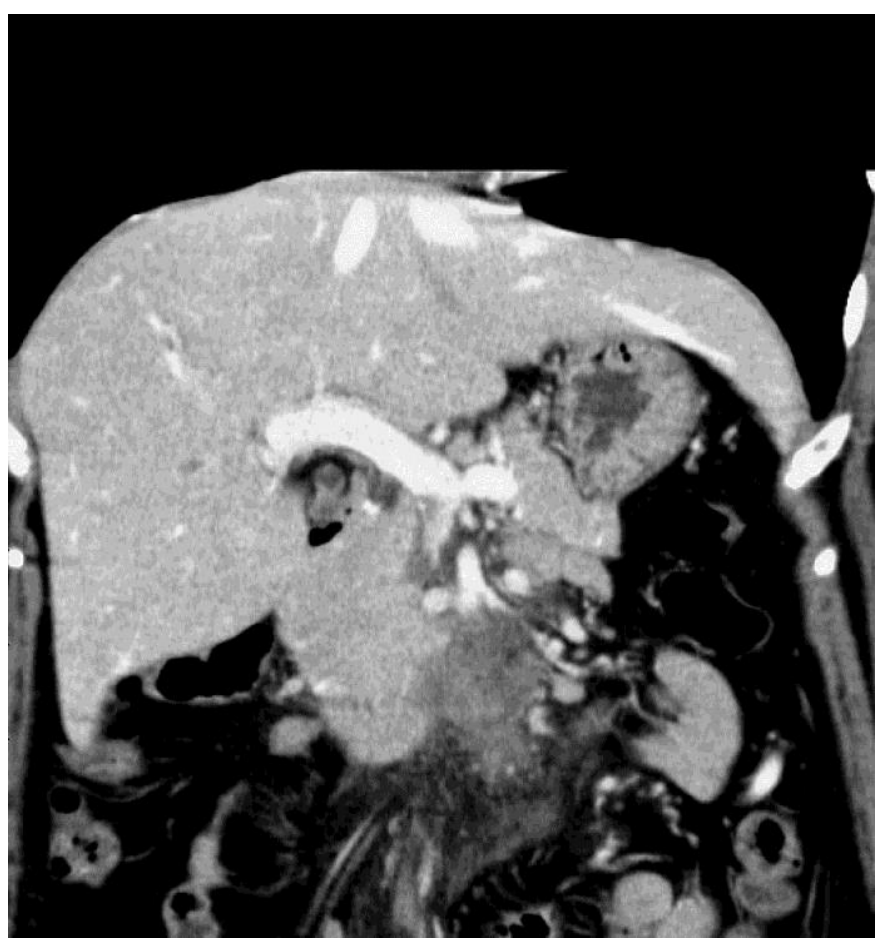

Fig. 1. Filling defect in the SMV extending to the peripheral vein of the jejunum. 


\section{Case Reports in Gastroenterology

\begin{tabular}{l|l}
\hline Case Rep Gastroenterol 2016;10:264-268 \\
\hline $10.1159 / 000446838$ & $\begin{array}{l}\text { @ 2016 The Author(s). Published by S. Karger AG, Basel } \\
\text { www.karger.com/crg }\end{array}$ \\
\hline
\end{tabular} \\ Koyama: Superior Mesenteric Vein Thrombosis Associated with Hormonal Contraceptive Use}

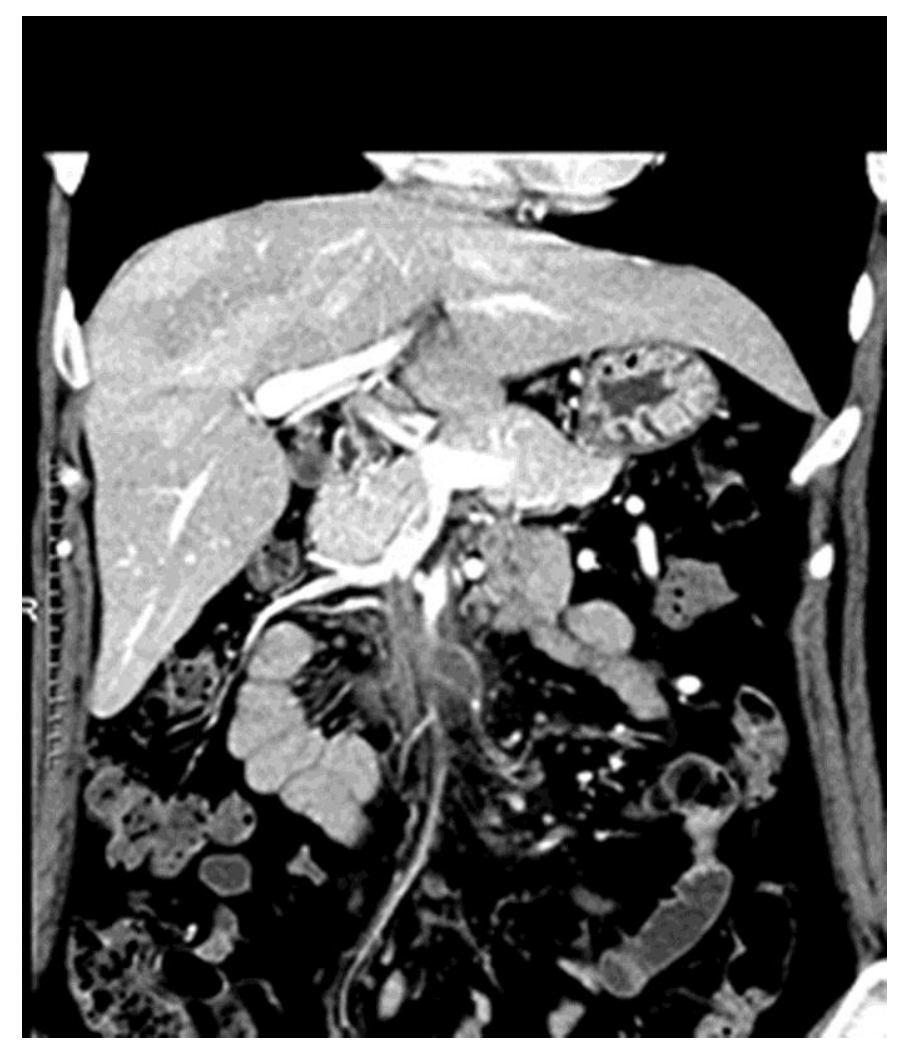

Fig. 2. Contrast-enhanced CT on the 13th day showing recanalization of the SMV.

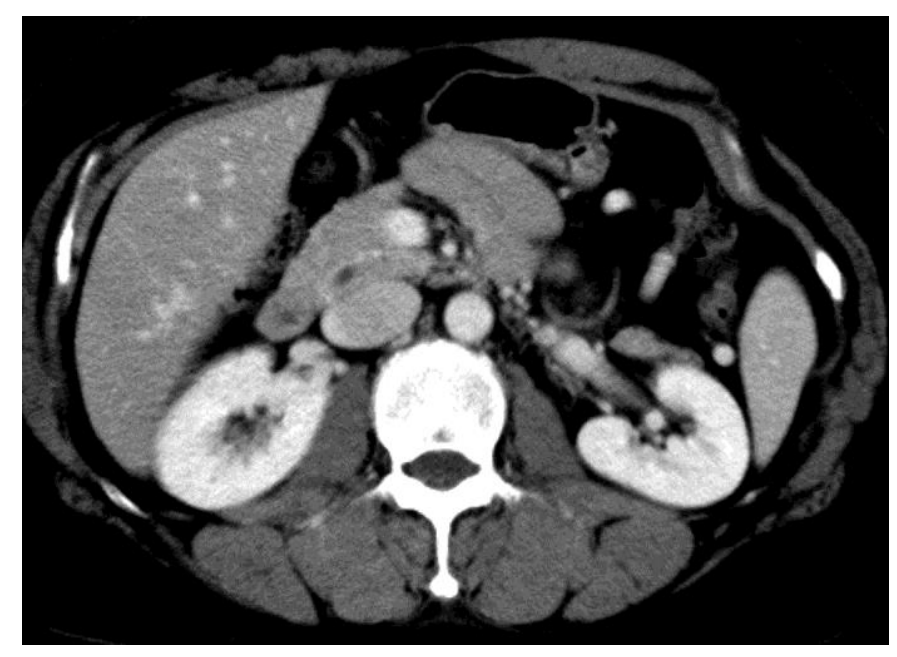

Fig. 3. The thrombus in the SMV disappeared after 3 months. 